\title{
Selective and Gram-Scale Synthesis of [6]Cycloparaphenylene
}

\section{AUTHOR(S):}

Kayahara, Eiichi; Patel, Vijay; Xia, Jianlong; Jasti, Ramesh; Yamago, Shigeru

\section{CITATION:}

Kayahara, Eiichi ...[et al]. Selective and Gram-Scale Synthesis of [6]Cycloparaphenylene. Synlett 2015, 26(11): 1615-1619

\section{ISSUE DATE:}

2015-06-19

URL:

http://hdl.handle.net/2433/201542

\section{RIGHT:}

(c) Georg Thieme Verlag Stuttgart - New York; The full-text file will be made open to the public on 19 June 2016 in accordance with publisher's 'Terms and Conditions for SelfArchiving'.; この論文は出版社版でありません。引用の際には出版社版をご確認ご利用く ださい。; This is not the published version. Please cite only the published version. 


\section{Selective and Gram-scale Synthesis of [6]Cycloparaphenylene}

\begin{abstract}
anstitute for Chemical Research, Kyoto University, Uji, Kyoto 611-0011, Japan

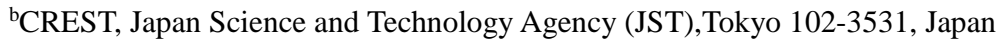
States

Fax: +81-774-38-3067

E-mail: yamago@scl.kyoto-u.ac.jp

Received: The date will be inserted once the manuscript is accepted.

Dedicated to Professor Peter Vollhardt on the occasion of his $69^{\text {th }}$ birthday

Abstract: The selective, practical and large scale synthesis of [6]cycloparaphenylene ([6]CPP), which is the second smallest CPP synthesized so far, was achieved in nine steps from commercially available starting materials: 1,4-dibromobenzene and 4-bromo-4'-hydroxybiphenyl. The key intermediate, cis1,4-(p-bromophenyl)-1,4-bis(triethylsiloxy)-2,5-cyclohexadiene, was prepared on a large scale $(>20 \mathrm{~g})$ and was selectively dimerized to form a cyclic precursor of [6]CPP via platinummediated assembly and subsequent reductive elimination. Deprotection of the triethylsilyl group and subsequent $\mathrm{H}_{2} \mathrm{SnCl}_{4}$-mediated reductive aromatization afforded [6]CPP in an overall yield of $23 \%$ from commercially available sources with $>1 \mathrm{~g}$ scale.
\end{abstract}

Eiichi Kayahara, , ${ }^{\text {ab }}$ Vijay Kumar Patel, ${ }^{\text {a,b }}$ Jianlong Xia, ${ }^{\mathrm{c}}$ Ramesh Jasti, ${ }^{\text {d }}$ Shigeru Yamago*a,b

'School of Chemistry, Chemical Engineering, and Life Science, Wuhan University of Technology, Wuhan 430070, China

${ }^{\mathrm{d} D e p a r t m e n t ~ o f ~ C h e m i s t r y ~ a n d ~ B i o c h e m i s t r y ~ a n d ~ M a t e r i a l s ~ S c i e n c e ~ I n s t i t u t e ~ 1253, ~ U n i v e r s i t y ~ o f ~ O r e g o n, ~ E u g e n e, ~ O r e g o n ~ 97403, ~ U n i t e d ~}$
Key words: cylcoparaphenylene, cyclization, organometallic reagents, platinum, tin

Cycloparaphenylenes (CPPs, Figure 1) have garnered significant interest due to their unique structure comprising the simplest structural unit of carbon nanotube sidewalls, as well as their vast potential in materials science and technology. ${ }^{1-8}$ Following the first synthesis of [9], [12], and [18]CPPs by Bertozzi and co-workers in 2008, ${ }^{9}$ significant progress has been made toward the synthesis of CPPs with different sizes and their analogues by Jasti, ${ }^{9-16}$ Itami, ${ }^{17-28}$ Yamago, ${ }^{29-35}$ and others. ${ }^{36-43}$ Accordingly, unique properties of CPPs, e.g., size-dependent photophysical $^{44-50}$ and redox properties ${ }^{31,51-55}$ and sizecomplementary host-guest chemistry, ${ }^{56-59}$ have been revealed.

The synthesis of small CPPs has recently attracted significant attention because smaller CPPs possess narrower HOMO-LUMO energy gaps (HOMO and LUMO refer to the highest occupied molecular orbital and the lowest unoccupied molecular orbital, respectively) than larger $\mathrm{CPPs},{ }^{31}$ which is advantageous for applications in organic electronic materials. For example, [5]CPP, which is the smallest CPP synthesized to date, possesses the most narrow

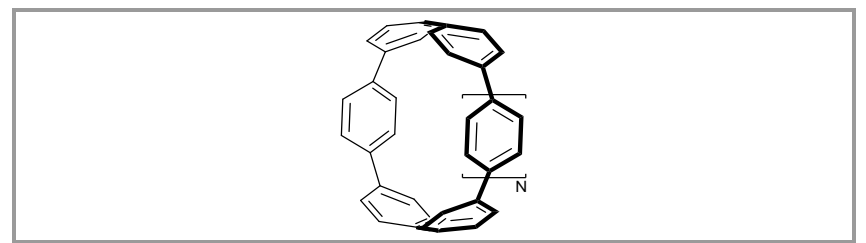

Figure 1 Structure of $[\mathrm{N}+6] \mathrm{CPP}$.
HOMO-LUMO gap among known CPPs and has a similar energy gap as that of $\mathrm{C}_{60} \cdot{ }^{34,14} \mathrm{In}$ addition, [5]CPP can be prepared on a large scale. ${ }^{60}$

On the contrary, [6]CPP, the second smallest CPP showing unique crystal packing in the solid state, was prepared by Jasti $^{13}$ and Yamago; 33 however, the reported methods were inefficient for the large-scale preparation of [6]CPP. Specifically, in Jasti's synthesis, cyclic precursor 1, which bears two cis-1,4dimethoxy-2,5-cyclohexadiene-1,4-diyl units, was reacted with 1,4-diborylbenzene to obtain 2, which was reductively aromatized using sodium naphthalenide at $-78{ }^{\circ} \mathrm{C}$ to obtain [6]CPP (Scheme 1a). However, the low coupling efficiency from 1 to $\mathbf{2}$, low overall yield $(0.7 \%)$, and harsh reaction conditions required to form [6]CPP from 2 limit the potential for the large-scale production. In Yamago's synthesis, bis-platinum complex 3 was homocoupled via nickel(0)-mediated Yamamoto coupling ${ }^{61,62}$ to obtain cyclic tetra-platinum complex $\mathbf{4}$, and subsequent reductive elimination of platinum gave [6]CPP in $8.7 \%$ overall yield (Scheme 1b). Despite the high yield of [6]CPP in this route, the use of four equivalents of platinum limits the practicality of this method.
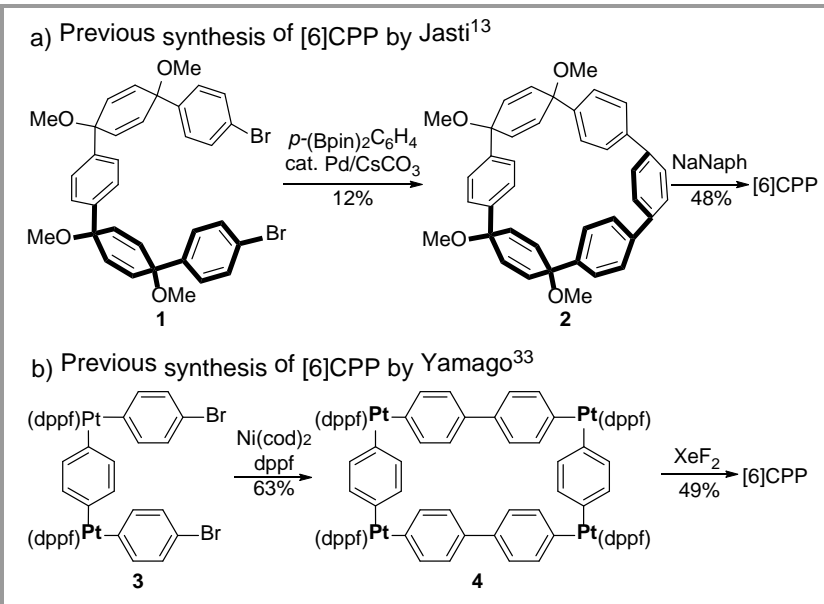

Scheme 1 Reported syntheses of [6]CPP

We envisioned that cis-1,4-dimethoxy-1,4-diaryl2,5-cyclohexadiene-1,4-diyl 5a $(\mathrm{R}=\mathrm{Me})$, which was 
used in the syntheses of [9], [12], and [18]CPPs and was prepared in large scale, ${ }^{9}$ would be an excellent precursor for [6]CPP (Scheme 2). If $\mathbf{5 a}$ is dimerized to form the cyclic precursor, reductive aromatization would give [6]CPP. Herein, we report the selective synthesis of [6]CPP based on such strategy. One of the author's group recently reported that cis-1,4dihydroxy-2,5-cyclohexadiene-1,4-diyl served as an excellent masked paraphenylene unit in the synthesis of CPPs and was aromatized under mild conditions. $^{34,60}$ Therefore, triethylsilyl (TES)protected precursor $\mathbf{5 b}(\mathrm{R}=\mathrm{TES})$ was mainly used as a starting material in this study.

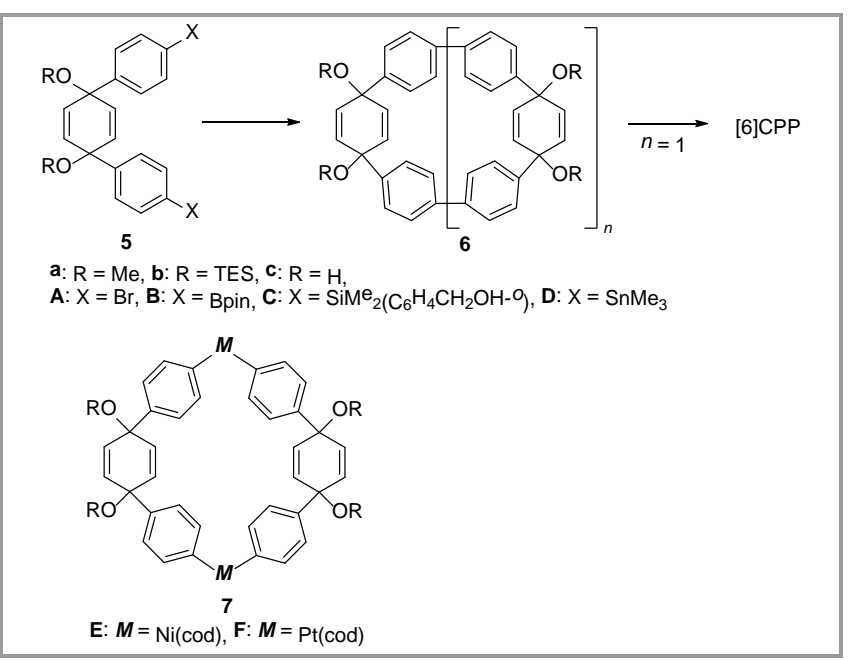

Scheme 2 Synthesis of [6]CPP

Cyclodimerization of dibromide 5bA $(\mathrm{R}=\mathrm{TES}, \mathrm{X}$ $=\mathrm{Br}$ ) via Yamamoto coupling was examined at first by mixing $5 \mathbf{b A}$ with $\mathrm{Ni}(\mathrm{cod})_{2}$ (2.0 equiv) and 2,2'bipyridyl (2.0 equiv) in refluxed THF. ${ }^{61,62}$ After a routine workup, the desired cyclic dimer $\mathbf{6 b}(n=1)$ was isolated in $11 \%$ yield (Scheme 2). The corresponding cyclic trimer $(n=2)$ and tetramer $(n=$ 3 ) were also obtained in $31 \%$ and $16 \%$ yield, respectively. The strain energies of the dimer $(n=1)$, trimer $(n=2)$, and tetramer $(n=3)$ of $\mathbf{6 c}(\mathrm{R}=\mathrm{H})$ were calculated to be 95,9 , and $16 \mathrm{~kJ} \mathrm{~mol}^{-1}$, respectively, using the B3LYP/6-31G* level of theory (see the Supporting Information). Therefore, the formation of a considerable amount of dimer $\mathbf{6 b}(n=1)$, in spite of its high strain energy, suggested that the product formation was kinetically controlled.

The Yamamoto coupling reaction involves the reduction of an aryl halide ( $\mathrm{ArX})$ by $\mathrm{Ni}(0)$ to form an $\mathrm{ArNi}(\mathrm{II}) \mathrm{X}$ species, ${ }^{63}$ a disproportionation reaction to form $\mathrm{Ar}_{2} \mathrm{Ni}(\mathrm{II}),{ }^{64,65}$ and subsequent reductive elimination to obtain the bisaryl product. As the disproportionation reaction is the rate-determining step and the reductive elimination of nickel from bisarylnickel takes place considerably fast, formation of bismetallated, cyclic intermediate 7E was less likely under the reactions conditions. Therefore, the low selectivity of the coupling reaction must be due to the short life time of the bisarylnickel(II) complex.
Although we examined several different reaction conditions, such as various ligands or solvents, the selective formation of the cyclic dimer could not be achieved.

The platinum-mediated dimerization of $\mathbf{5}$ was examined next. TES-protected bispinacolborane $\mathbf{5 b B}$ $(\mathrm{R}=\mathrm{TES}, \mathrm{X}=\text { Bpin; pin refers to pinacolate })^{60}$ was treated with $\mathrm{Pt}(\mathrm{cod}) \mathrm{Cl}_{2}$ (cod refers to 1,5cyclooctadiene) (1.0 equiv) and $\mathrm{K}_{3} \mathrm{PO}_{4}$ (10 equiv) in THF at $60{ }^{\circ} \mathrm{C}$ for $84 \mathrm{~h}$, and the desired bisplatinum complex $\mathbf{7 b F}$ (R = TES, $M=\mathrm{Pt}(\mathrm{cod})$ ) was obtained in $59 \%$ yield. Notably, $\mathbf{7 b F}$ was also prepared in $51 \%$ yield by mixing bissilane 5bC $[\mathrm{R}=\mathrm{TES}, \mathrm{X}=$ $\left.\mathrm{SiMe}_{2}\left(\mathrm{C}_{6} \mathrm{H}_{4} \mathrm{CH}_{2} \mathrm{OH}-o\right)\right],{ }^{66} \mathrm{Pt}(\operatorname{cod}) \mathrm{Cl}_{2}$ (1.0 equiv), and $\mathrm{K}_{3} \mathrm{PO}_{4}$ (5.0 equiv) in THF at $60{ }^{\circ} \mathrm{C}$. The reaction between bis-stannane $5 \mathbf{b D}\left(\mathrm{R}=\mathrm{TES}, \mathrm{X}=\mathrm{SnMe}_{3}\right)$ and $\mathrm{Pt}(\mathrm{cod}) \mathrm{Cl}_{2}$ was most effective and gave $\mathbf{7 b F}$ in $78 \%$ yield. The platinum-mediated dimerization was also successful by mixing a $1: 1$ mixture of $5 \mathrm{aD}(\mathrm{R}=\mathrm{Me}$, $\mathrm{X}=\mathrm{SnMe}_{3}$ ) and $\mathrm{Pt}(\mathrm{cod}) \mathrm{Cl}_{2}$ to give $\mathbf{7 a F}$ in $66 \%$ yield. Starting from $4.0 \mathrm{~g}$ of $5 \mathbf{b D}, 4.5 \mathrm{~g}$ of $7 \mathbf{a F}$ was synthesized. The highly efficient formation of $\mathbf{7 F}$ is attributed to the sufficiently long life time and stability of the bisarylplatinum(II) complex to the reductive elimination.

Reductive elimination of platinum from $7 \mathbf{b F}$ was carried out by heating a toluene solution of $\mathbf{7 b F}$ with $\mathrm{PPh}_{3}$ (4 equiv) at $90{ }^{\circ} \mathrm{C}$ for $17 \mathrm{~h}$; the TES-protected cyclic dimer $\mathbf{6 b}(n=1)$ was obtained in $70 \%$ yield. We previously reported several conditions for the reductive elimination of platinum in the synthesis of CPPs; however, the use of $\mathrm{PPh}_{3}$ was the most efficient. Upon treatment of $\mathbf{6 b}$ with tetrabutylammonium fluoride (TBAF), cyclic dimer 6c $(\mathrm{R}=\mathrm{H}, n=1)$, bearing two 1,4-dihydroxy-2,5cyclohexadiene-1,4-diyl units, was obtained quantitatively. More than $4.5 \mathrm{~g}$ of $\mathbf{6 c}$ was synthesized. Methoxy-derivative $\mathbf{7 a F}$ was also transformed into $\mathbf{6 a}$ $(n=1)$ in $78 \%$ yield by using $\mathrm{PPh}_{3}$ (4 equiv) at $90^{\circ} \mathrm{C}$ for $17 \mathrm{~h}$.

The structure of $\mathbf{6 a - c}$ was characterized using ${ }^{1} \mathrm{H}$ and ${ }^{13} \mathrm{C}$ NMR and ESI-TOF mass spectrometry. In the ${ }^{1} \mathrm{H}$ NMR spectra, the aromatic protons on the biphenyl bridges were shielded, and were observed around $\delta=$ 6.7-6.9 ppm in all compounds, indicating that all compounds possessed similar structures and conformations, where the two biphenyl bridges were in close proximity. The structure of $\mathbf{6 a}$ was unambiguously determined by single crystal X-ray analysis (Figure 2). The biphenyl bridges were about 3.82-4.55 A apart, and this distance was

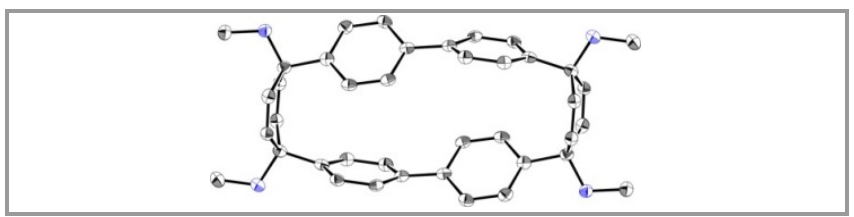

Figure 2 ORTEP drawing of $\mathbf{6 a}$. Thermal ellipsoids are shown at $50 \%$ probability. Hydrogen and solvent atoms are omitted for clarity. 
consistent with the shielding effect observed in the ${ }^{1} \mathrm{H}$ NMR. The biphenyl units were twisted with a dihedral angle in the range of $44.8(4)^{\circ}-38.5(2)^{\circ}$. Moreover, all methoxy groups extended outward from the cyclic ring structure, suggesting that protecting groups did not affect the structure of the cyclic skeleton. The structural characteristics clarified by X-ray analysis were consistent with the ${ }^{1} \mathrm{H}$ NMR data.

Cyclic dimer 6c was subjected to reductive aromatization with $\mathrm{H}_{2} \mathrm{SnCl}_{4},{ }^{60}$ which was prepared in situ by mixing $\mathrm{SnCl}_{2} \cdot 2 \mathrm{H}_{2} \mathrm{O}$ (4.4 equiv) and conc. $\mathrm{HCl}$ (8.8 equiv) in THF at room temperature for $22 \mathrm{~h}$. After a routine workup, [6]CPP was isolated in 95\% yield following silica gel chromatography. More than $1 \mathrm{~g}$ $(1.33 \mathrm{~g})$ of [6]CPP was synthesized. As 5bA was prepared from 1,4-dibromobenzene and 4-bromo-4'hydroxybiphenyl in four steps and three pots in $64 \%$ yield, the overall yield of [6]CPP from commercially available sources was $23 \%$, which was significantly higher than that obtained in previous reports. ${ }^{13,33}$ Reductive aromatization of methoxy-protected $\mathbf{6 a}$ was also carried out using sodium naphthalenide (6.0 equiv) at $-78{ }^{\circ} \mathrm{C}$ for $2 \mathrm{~h}$, although this route was less effective (38\% yield) than that from $\mathbf{6 c}$. These results also clarified the synthetic advantage of the 1,4dihydroxy-2,5-cyclohexadiene-1,4-diyl precursor for the large-scale synthesis of CPPs.

In summary, we established an efficient and practical synthetic route for [6]CPP. While a stoichiometric amount of platinum was still required, it was substantially less than that required in previously reported method. Furthermore, the mild conditions and high-yielding reductive aromatization step, owing to the use of the dihydroxy-containing precursor, make this synthetic route attractive for the mass production of [6]CPP.

Supporting Information for this article is available online at http://www.thiemeconnect.com/products/ejournals/journal/10.1055/s00000083.

Primary Data for this article are available online at http://www.thiemeconnect.com/products/ejournals/journal/10.1055/s00000083 and can be cited using the following DOI: (number will be inserted prior to online publication).

\section{Acknowledgments}

This work was partly supported by the CREST Program of the Japan Science and Technology Agency (SY) and by a Grant-in-Aid for Scientific Research (C) (Grant Number 26410043 to EK). Single-crystal $\mathrm{X}$-ray analysis was performed at BL02B1 of SPring-8 with the approval of the Japan Synchrotron Radiation Research Institute (JASRI; 2014B1203). We thank Dr. Kunihisa Sugimoto (JASRI) and Dr. Nobuhiro Yasuda (JASRI) for their valuable discussions and suggestions regarding X-ray crystallographic analysis.

\section{References}

(1) Schröder, A.; Mekelburger, H.-B.; Vögtle, F. Top. Curr. Chem. 1994, 172, 179.

(2) Scott, L. T. Angew. Chem. Int. Ed. 2003, 42, 4133.

(3) Kawase, T.; Kurata, H. Chem. Rev. 2006, 106, 5250.

(4) Tahara, K.; Tobe, Y. Chem. Rev. 2006, 106, 5274.

(5) Steinberg, B. D.; Scott, L. T. Angew. Chem. Int. Ed. 2009, 48, 5400 .

(6) Eisenberg, D.; Shenhar, R.; Rabinovitz, M. Chem. Soc. Rev. 2010, 39, 2879.

(7) Iyoda, M.; Yamakawa, J.; Rahman, M. J. Angew. Chem. Int. Ed. 2011, 50, 10522.

(8) Evans, P. J.; Jasti, R. Top. Curr. Chem. 2013, 4, 1.

(9) Jasti, R.; Bhattacharjee, J.; Neaton, J. B.; Bertozzi, C. R. J. Am. Chem. Soc. 2008, 130, 17646.

(10) Sisto, T. J.; Golder, M. R.; Hirst, E. S.; Jasti, R. J. Am. Chem. Soc. 2011, 133, 15800.

(11) Darzi, E. R.; Sisto, T. J.; Jasti, R. J. Org. Chem. 2012, 77, 6624.

(12) Xia, J.; Bacon, J. W.; Jasti, R. Chem. Sci. 2012, 3, 3018.

(13) Xia, J.; Jasti, R. Angew. Chem. Int. Ed. 2012, 51, 2474.

(14) Evans, P. J.; Darzi, E. R.; Jasti, R. Nat. Chem. 2014, 6, 404.

(15) Xia, J.; Golder, M. R.; Foster, M. E.; Wong, B. M.; Jasti, R. J. Am. Chem. Soc. 2012, 134, 19709.

(16) Sisto, T. J.; Tian, X.; Jasti, R. J. Org. Chem. 2012, 77, 5857.

(17) Takaba, H.; Omachi, H.; Yamamoto, Y.; Bouffard, J.; Itami, K. Angew. Chem. Int. Ed. 2009, 48, 6112.

(18) Omachi, H.; Matsuura, S.; Segawa, Y.; Itami, K. Angew. Chem. Int. Ed. 2010, 49, 10202.

(19) Segawa, Y.; Miyamoto, S.; Omachi, H.; Matsuura, S.; Šenel, P.; Sasamori, T.; Tokitoh, N.; Itami, K. Angew. Chem. Int. Ed. 2011, 50, 3244.

(20) Segawa, Y.; Šenel, P.; Matsuura, S.; Omachi, H.; Itami, K. Chem. Lett. 2011, 40, 423.

(21) Ishii, Y.; Nakanishi, Y.; Omachi, H.; Matsuura, S.; Matsui, K.; Shinohara, H.; Segawa, Y.; Itami, K. Chem. Sci. 2012, 3, 2340.

(22) Sibbel, F.; Matsui, K.; Segawa, Y.; Studer, A.; Itami, K. Chem. Comm. 2014, 50, 954.

(23) Omachi, H.; Segawa, Y.; Itami, K. Org. Lett. 2011, 13, 2480.

(24) Yagi, A.; Segawa, Y.; Itami, K. J. Am. Chem. Soc. 2012, 134, 2962.

(25) Matsui, K.; Segawa, Y.; Itami, K. Org. Lett. 2012, 14, 1888.

(26) Matsui, K.; Segawa, Y.; Itami, K. J. Am. Chem. Soc. 2014, 136, 16452.

(27) Yagi, A.; Venkataramana, G.; Segawa, Y.; Itami, K. Chem. Commun. 2014, 50, 957.

(28) Ishii, Y.; Matsuura, S.; Segawa, Y.; Itami, K. Org. Lett. 2014, 16, 2174.

(29) Iwamoto, T.; Kayahara, E.; Yasuda, N.; Suzuki, T.; Yamago, S. Angew. Chem. Int. Ed. 2014, 53, 6430. 
(30) Yamago, S.; Watanabe, Y.; Iwamoto, T. Angew. Chem. Int. Ed. 2010, 49, 757.

(31) Iwamoto, T.; Watanabe, Y.; Sakamoto, Y.; Suzuki, T.; Yamago, S. J. Am. Chem. Soc. 2011, 133, 8354.

(32) Kayahara, E.; Sakamoto, Y.; Suzuki, T.; Yamago, S. Org. Lett. 2012, 14, 3284.

(33) Kayahara, E.; Iwamoto, T.; Suzuki, T.; Yamago, S. Chem. Lett. 2013, 42, 621.

(34) Kayahara, E.; Patel, V. K.; Yamago, S. J. Am. Chem. Soc. 2014, 136, 2284.

(35) Kayahara, E.; Iwamoto, T.; Takaya, H.; Suzuki, T.; Fujitsuka, M.; Majima, T.; Yasuda, N.; Matsuyama, N.; Seki, S.; Yamago, S. Nat. Commun. 2013, 4, 2694.

(36) Hitosugi, S.; Nakanishi, W.; Yamasaki, T.; Isobe, H. Nat. Commun 2011, 2, 492.

(37) Hitosugi, S.; Yamasaki, T.; Isobe, H. J. Am. Chem. Soc. 2012, 134, 12442.

(38) Nishiuchi, T.; Feng, X.; Enkelmann, V.; Wagner, M.; Müllen, K. Chem. Eur. J. 2012, 18, 16621.

(39) Golling, F. E.; Quernheim, M.; Wagner, M.; Nishiuchi, T.; Müllen, K. Angew. Chem. Int. Ed. 2014, 53, 1525.

(40) Batson, J. M.; Swager, T. M. Synlett 2013, 24, 2545.

(41) Tran-Van, A.-F.; Huxol, E.; Basler, J. M.; Neuburger, M.; Adjizian, J.-J.; Ewels, C. P.; Wegner, H. A. Org. Lett. 2014, 16, 1594.

(42) Huang, C.; Huang, Y.; Akhmedov, N. G.; Popp, B. V.; Petersen, J. L.; Wang, K. K. Org. Lett. 2014, 16, 2672.

(43) Jiang, H.-W.; Tanaka, T.; Mori, H.; Park, K. H.; Kim, D.; Osuka, A. J. Am. Chem. Soc. 2015, 137, 2219.

(44) Segawa, Y.; Fukazawa, A.; Matsuura, S.; Omachi, H.; Yamaguchi, S.; Irle, S.; Itami, K. Org. Biomol. Chem. 2012, 10, 5979.

(45) Fujitsuka, M.; Cho, D. W.; Iwamoto, T.; Yamago, S.; Majima, T. Phys. Chem. Chem. Phys. 2012, 14, 14585.

(46) Nishihara, T.; Segawa, Y.; Itami, K.; Kanemitsu, Y. J. Phys. Chem. Lett. 2012, 3, 3125.

(47) Fujitsuka, M.; Iwamoto, T.; Kayahara, E.; Yamago, S.; Majima, T. ChemPhysChem 2013, 14, 1570.

(48) Chen, H.; Golder, M. R.; Wang, F.; Jasti, R.; Swan, A. K. Carbon 2014, 67, 203.

(49) Fujitsuka, M.; Lu, C.; Iwamoto, T.; Kayahara, E.; Yamago, S.; Majima, T. J. Phys. Chem. A 2014, 118, 4527.

(50) Alvarez, M. P.; Burrezo, P. M.; Kertesz, M.; Iwamoto, T.; Yamago, S.; Xia, J.; Jasti, R.; Navarrete, J. T. L.; Taravillo, M.; Baonza, V. G.; Casado, J. Angew. Chem. Int. Ed. 2014, 53, 7033.

(51) Kayahara, E.; Kouyama, T.; Kato, T.; Takaya, H.; Yasuda, N.; Yamago, S. Angew. Chem. Int. Ed. 2013, 52, 13722.
(52) Golder, M. R.; Wong, B. M.; Jasti, R. Chem. Sci. 2013, 4, 4285.

(53) Zabula, A. V.; Filatov, A. S.; Xia, J.; Jasti, R.; Petrukhina, M. A. Angew. Chem. Int. Ed. 2013, 52, 5033.

(54) Fujitsuka, M.; Tojo, S.; Iwamoto, T.; Kayahara, E.; Yamago, S.; Majima, T. J. Phys. Chem. Lett. 2014, 5, 2302.

(55) Toriumi, N.; Muranaka, A.; Kayahara, E.; Yamago, S.; Uchiyama, M. J. Am. Chem. Soc. 2015, 137, 82.

(56) Iwamoto, T.; Watanabe, Y.; Sadahiro, T.; Haino, T.; Yamago, S. Angew. Chem. Int. Ed. 2011, 50, 8342.

(57) Iwamoto, T.; Watanabe, Y.; Takaya, H.; Haino, T.; Yasuda, N.; Yamago, S. Chem. Eur. J. 2013, 19, 14061.

(58) Nakanishi, Y.; Omachi, H.; Matsuura, S.; Miyata, Y.; Kitaura, R.; Segawa, Y.; Itami, K.; Shinohara, H. Angew. Chem. Int. Ed. 2014, 53, 3102.

(59) Iwamoto, T.; Slanina, Z.; Mizorogi, N.; Guo, J.; Akasaka, T.; Nagase, S.; Takaya, H.; Yasuda, N.; Kato, T.; Yamago, S. Chem. Eur. J. 2014, 20, 14403.

(60) Patel, V. K.; Kayahara, E.; Yamago, S. Chem. Eur. J. 2015, 21, 5742.

(61) Yamamoto, T.; Wakabayashi, S.; Osakada, K. J. Organomet. Chem. 1992, 428, 223.

(62) Osakada, K.; Sato, R.; Yamamoto, T. Organometallics 1994, 13, 4645.

(63) Abla, M.; Yamamoto, T. Bull. Chem. Soc. Jpn. 1999, 72, 1255.

(64) Matsumoto, H.; Inaba, S.; Rieke, R. D. J. Org. Chem. 1983, 48, 840.

(65) Osakada, K.; Yamamoto, T. Coord. Chem. Rev. 2000, 198, 379.

(66) Nakao, Y.; Imanaka, H.; Sahoo, A. K.; Yada, A.; Hiyama, T. J. Am. Chem. Soc. 2005, 127, 6952. 


\section{Synthesis of [6]Cycloparaphenylene}

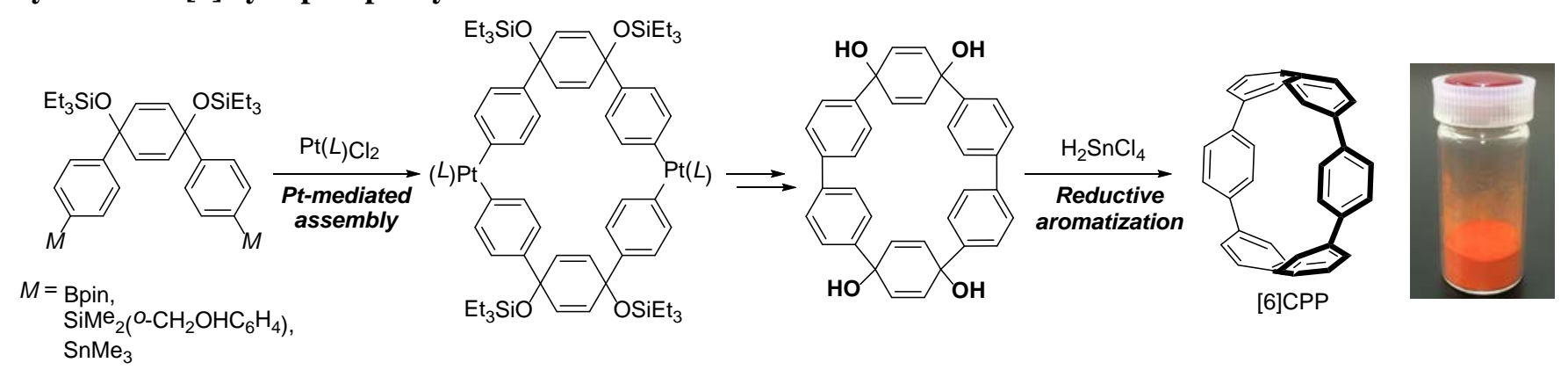

